University of Nebraska - Lincoln

DigitalCommons@University of Nebraska - Lincoln

Nebraska Game and Parks Commission -- Staff

Research Publications

Nebraska Game and Parks Commission

April 1965

\title{
Age and Growth of the River Carpsucker, Carpiodes carpio, in the Missouri River
}

Larry A. Morris

Nebraska Game, Forestation and Parks Commission, Lincoln, Nebraska

Follow this and additional works at: https://digitalcommons.unl.edu/nebgamestaff

Part of the Environmental Sciences Commons

Morris, Larry A., "Age and Growth of the River Carpsucker, Carpiodes carpio, in the Missouri River" (1965). Nebraska Game and Parks Commission -- Staff Research Publications. 12.

https://digitalcommons.unl.edu/nebgamestaff/12

This Article is brought to you for free and open access by the Nebraska Game and Parks Commission at DigitalCommons@University of Nebraska - Lincoln. It has been accepted for inclusion in Nebraska Game and Parks Commission -- Staff Research Publications by an authorized administrator of DigitalCommons@University of Nebraska - Lincoln. 


\title{
Age and Growth of the River Carpsucker, Carpiodes carpio, in the Missouri River
}

\author{
LARRY A. MORRIS
}

\section{$\boldsymbol{\nabla}$}

Reprinted from

THE AMERICAN MIDLAND NATURALIST

Vol. 73, No. 2, pp. 423-429, April, 1965

University of Notre Dame Press

Notre Dame, Indiana 


\title{
Age and Growth of the River Carpsucker, Carpiodes carpio, in the Missouri River ${ }^{1}$
}

\author{
LARRY A. MORRIS \\ Nebraska Game, Forestation and Parks Commission, Lincoln, Nebraska
}

\begin{abstract}
The river carpsucker, Carpiodes carpio, was collected in the Missouri River bordering eastern Nebraska in 1961 and 1962. During and preceding the study period the course of the river was being altered to promote commercial barge traffic. These alterations resulted in numerous cutoff lakes and chutes many of which were left open to the river at their downstream ends. Collections were made both here and in the river channel. Age and growth data from collections in the cutoff lakes and chutes were combined, while age and growth determinations were made separately for fish from the main stream. The differences in average calculated growth rates of the two groups were slight. The greatest increment of growth occurred during the second year. Female river carpsuckers grew slightly faster than the males through the first four years of life. Usually the river carpsuckers were mature when 12 inches long. About $25 \%$ of the threeyear-old males were mature and approximately $25 \%$ of the fouryear-old females had reached maturity. A length-weight relationship and coefficients of condition are presented.
\end{abstract}

\section{InTRODUCTION}

The river carpsucker, Carpiodes carpio (Rafinesque), has received comparatively little attention in fishery investigations. The species has little economic importance and is not often taken by the angler. Nevertheless, an understanding of the life history of the river carpsucker adds to the knowledge of species interaction in the aquatic community. This fish competes with others for space and probably for food at some time during its life cycle. In addition, through the early part of its life, it serves as a food source for many other fishes.

River carpsuckers were collected from the Missouri River, for 110 river miles, between Omaha, Nebraska, and Sioux City, Iowa. During and preceding the study period, the course of the river was being modified to facilitate commercial barge traffic between the two cities. As a part of this modification the flow was diverted in many places through more direct, excavated channels. Many segments of the original channel were thus left as man-made oxbows or "cutoff lakes" which were separated from the new channel by dikes at their upper ends. Some remained connected to the river at their lower ends. The river channel as modified was generally narrower and deeper than the original one throughout the studied portion.

Also, as a part of this modification, retaining dikes were built to deflect the current and contain the stream within the new, narrower channel. Behind these, secondary channels carried ground water downstream to flow eventually into the new channel. These

${ }^{1}$ A contribution of Federal Aid in Fish Restoration, Project F-4-R, Nebraska. 
slowly flowing waters were much like miniature cutoff lakes and were termed "chutes."

Fish collections in cutoff lakes and chutes were made only in those which opened into the river at their downstream ends.

Acknowledgments. - The author gratefully acknowledges the helpful advice and assistance offered by personnel of the Research Section of the Nebraska Game, Forestation and Parks Commission. Special thanks are owed Dr. Arthur Witt, Jr., of the University of Missouri, who critically reviewed the manuscript.

\section{Methods and Materials}

Collections of river carpsuckers were made between June and November of 1961 and between April and June of 1962. A total of 247 specimens was collected in the cutoff lakes and chutes. Fortyone additional individuals were taken from the main stream of the river. Still sets of both gill and trammel nets in the cutoff lakes and chutes yielded good catches of river carpsuckers over six inches in length. Nets set perpendicular to the shore in water less than six feet in depth were more effective in capturing river carpsuckers than were nets set in deeper water. Seining of shallow water areas in cutoff lakes and chutes with a 40-foot bag seine was effective in capturing river carpsuckers less than six inches long. Specimens were collected from the main stream of the river in November by drifting a trammel net over the shallow sand bars.

Data for calculations of growth rates were combined for fish from the cutoff lakes and chutes. Calculations of growth rates were made independently for fish collected from the main stream. A comparison of the results of these calculations is presented later.

Sex determination of many individuals under six inches total length was difficult and believed to be unreliable. Therefore, many fish of this size range were simply recorded as being immature.

Scale measurements were made along the most central anterior radius of the scale image from the center of the focus to the edge of the scale. Buchholz (1957) and Bass and Riggs (1959) have measured scale length in lateral areas of the river carpsucker scale because of less variation in radius length and because annuli were sometimes more discernible in this area. Nevertheless, the central anterior radius was used in the present study because false annuli appeared more frequently in the lateral fields of the scale.

There was little variation in total length and standard length conversion factors through the various size groups, so only average values are presented. Average standard length and total length conversion factors for 148 fish from 2.4 to 16.9 inches total length are as follows: $\mathrm{SL}=0.77 \mathrm{TL} ; \mathrm{TL}=1.29 \mathrm{SL}$.

\section{Age and Growth}

Annulus identification.-Identification of true annuli on the scales of the river carpsuckers proved to be difficult as no single criterion was usable in every case. In addition, false annuli were frequently encountered in scales of fish from all age groups, but were most noticeable in older fish. No general areas on the scales could consis- 
tently be relied upon for locating annuli as these fish exhibited a wide range in growth rates (Table 1). Buchholz (1957) and Bass and Riggs (1959) have also encountered difficulty in determining true annuli in river carpsucker scales.

A combination of criteria was finally used to identify annuli. For the first few years of life, annuli were often characterized by cutting over in the lateral fields of the scale. Spacing of the circuli also proved useful in helping to identify annuli. The year mark was often preceded by a band of narrow circuli closely aligned and was followed by broader, more widely spaced circuli. In addition to broadening, circuli in the posterior lateral fields of the scale often grew at an outwardly oblique angle to normal growth immediately after annulus formation.

TABLE 1.-Length frequency distribution, in millimeters, of 247 river carpsuckers of both sexes from cutoff lakes and chutes along the Missouri River in Nebraska

\begin{tabular}{|c|c|c|c|c|c|c|c|}
\hline \multirow{2}{*}{$\begin{array}{l}\text { Class interval } \\
\text { Total length }\end{array}$} & \multirow[b]{2}{*}{ I } & \multicolumn{5}{|c|}{ Age groups } & \multirow[b]{2}{*}{ VII } \\
\hline & & II & III & IV & V & VI & \\
\hline $60-69$ & 8 & & & & & & \\
\hline $70-79$ & 11 & & & & & & \\
\hline $80-89$ & 13 & & & & & & \\
\hline $90-99$ & 15 & & & & & & \\
\hline $100-109$ & 6 & & & & & & \\
\hline $110-119$ & 4 & & & & & & \\
\hline $120-129$ & 2 & & & & & & \\
\hline $130-139$ & 1 & 1 & & & & & \\
\hline $140-149$ & 2 & & & & & & \\
\hline $150 \cdot 159$ & 4 & & & & & & \\
\hline $160-169$ & 1 & 5 & & & & & \\
\hline $170-179$ & & 5 & & & & & \\
\hline $180-189$ & & 3 & & & & & \\
\hline $190-199$ & 2 & 6 & 1 & & & & \\
\hline $200-209$ & & 4 & 3 & & & & \\
\hline $210-219$ & 1 & 3 & 3 & & & & \\
\hline $220-229$ & & 5 & 8 & 1 & & & \\
\hline $230-239$ & & 3 & 7 & 1 & & & \\
\hline $240-249$ & & 5 & 17 & 7 & & & \\
\hline $250-259$ & & 5 & 7 & 10 & & & \\
\hline $260-269$ & & 1 & 2 & 4 & & & \\
\hline $270-279$ & & & 3 & 9 & 1 & & \\
\hline $280-289$ & & & 2 & 5 & 1 & & \\
\hline $290-299$ & & & & 8 & 5 & & \\
\hline $300-309$ & & & 2 & 7 & 4 & 1 & \\
\hline $310-319$ & & & & 2 & 3 & & \\
\hline $320-329$ & & & & & 1 & & \\
\hline $330-339$ & & & & 1 & 1 & 1 & \\
\hline $350-359$ & & & & & & 1 & \\
\hline $360-369$ & & & & & 1 & & \\
\hline $420-429$ & & & & & & & 1 \\
\hline Frequency & 70 & 46 & 55 & 55 & 17 & 3 & 1 \\
\hline Average total length & 100 & 209 & 243 & 275 & 307 & 332 & 424 \\
\hline Range & $61-213$ & $132-259$ & $196-305$ & $227-330$ & $274-3663$ & $305-356$ & 0 \\
\hline
\end{tabular}


Body-scale relationship.-A body length-scale relationship for 247 river carpsuckers from the cutoff lakes and chutes was determined by grouping the total lengths into $10-\mathrm{mm}$ class intervals and plotting the average of each interval against the corresponding average scale length in millimeters times 47.5 (Fig. 1). The relationship between these points is probably sigmoid; however, a straight line adequately describes this relationship and was calculated by the method of least squares to be: $\mathrm{L}=10.2+1.16$ (SL) where $\mathrm{L}$ is the total length in millimeters and SL is the anterior scale radius in millimeters times 47.5. Back calculations of lengths were made as described by Carlander and Smith (1944).

Growth.-Calculated lengths of both sexes have been combined for the discussion of growth (Table 2). It will be seen that these fish grew at a relatively uniform rate through the first three years of life. Thereafter, growth slowed considerably. The greatest average annual increment of growth occurred during the second year, with growth in the first and third growing seasons being about equal. Established growth rates for many species of fish indicate that the greatest increment often occurs during the first year of life with succeeding increments being less. Buchholz (1957) also found that the greatest increment of growth for river carpsuckers in the Des Moines River, Iowa, occurred during the second year. The smaller growth increment during the first year may be partially explained by the spawning habits of this species. Starrett $(1948)$ concluded that the river carpsucker is an intermittent spawner, and Brezner (1956) consid-

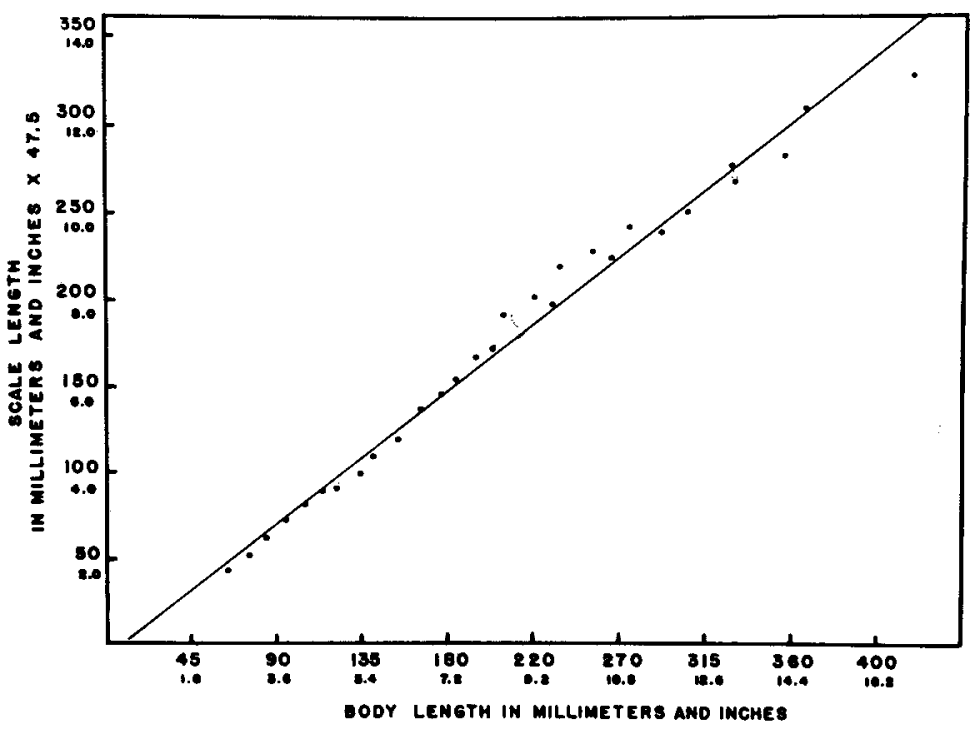

Fig. 1.--The body-scale relationship of river carpsuckers from the cutoff lakes and chutes along the Missouri River in Nebraska. 
ered the spawning time of this species in Missouri to extend from April through June. An extended spawning period and resulting shorter growing season for late spawned individuals could account for the smaller average growth increment during the first rather than the second year of life when the growing season would be nearly the same for all yearling carpsuckers. Appleget and Smith (1951) related a small growth during the first year of life of channel catfish in the Mississippi River to the late hatching time of this species.

Average annual growth rates were calculated for 81 male and 84 female river carpsuckers from the cutoff lakes and chutes. The females averaged 0.3 inch larger than the males during each year of life through the first four years. Thereafter, the sample size was small, but at the end of the fifth year (21 individuals) calculated growth rates were the same for both sexes, and in the sixth year (4 individuals) growth of the males exceeded that of the females by 0.4 inch. The largest (17 inches) and oldest fish collected during the present study was a seven-year-old male.

Buchholz (1957) and Bass and Riggs (1959) have demonstrated Lee's phenomenon of apparent change in calculated growth rates of older fish in river carpsucker populations. Examination of average calculated lengths (Table 2) for each age group where frequencies are large enough to be reliable indicates that Lee's phenomenon is present in this population.

Forty-one river carpsuckers were collected by drifting a trammel net in the main stream of the river. Scale samples were obtained from 36 of these fish. Growth of these specimens, age groups II through $\mathrm{V}$, was calculated by using the equation previously computed for the 247 river carpsuckers from the cutoff lakes and chutes.

The differences in average calculated growth rates of the two groups were slight. The total lengths of the 36 fish from the main stream averaged less than 0.2 inch shorter at each year than the total

TABLE 2.-Average calculated lengths, in millimeters, of 247 river carpsuckers of both sexes from cutoff lakes and chutes along the Missouri River in Nebraska

\begin{tabular}{|c|c|c|c|c|c|c|c|c|c|}
\hline \multirow{2}{*}{$\begin{array}{l}\text { Age } \\
\text { Group }\end{array}$} & & $\begin{array}{c}\text { Total } \\
\text { length at }\end{array}$ & \multicolumn{7}{|c|}{ Length at the end of each year of life } \\
\hline & Frequency & capture & 1 & 2 & 3 & 4 & 5 & 6 & 7 \\
\hline I & 70 & 100 & 74 & & & & & & \\
\hline II & 46 & 209 & 85 & 186 & & & & & \\
\hline III & 55 & 243 & 75 & 156 & 231 & & & & \\
\hline IV & 55 & 275 & 72 & 144 & 212 & 266 & & & \\
\hline $\mathrm{V}$ & 17 & 307 & 57 & 130 & 199 & 254 & 302 & & \\
\hline VI & 3 & 332 & 70 & 132 & 200 & 266 & 312 & 332 & \\
\hline VII & 1 & 424 & 56 & 190 & 261 & 328 & 380 & 403 & 424 \\
\hline$\overline{\text { Weigh }}$ & ted average & e length & 74 & 157 & 218 & 264 & 307 & 350 & 424 \\
\hline Avera & ge increme & & 74 & 83 & 71 & 55 & 48 & 21 & 21 \\
\hline Weigh & ted average & length & & & & & & & \\
\hline in & inches & & 3.0 & 6.3 & 8.7 & 10.6 & 12.3 & 14.0 & 17.0 \\
\hline Avera & ge incremer & at in inches & 3.0 & 3.3 & 2.8 & 2.2 & 1.9 & 0.8 & 0.8 \\
\hline
\end{tabular}


lengths of the fish from the cutoff lakes and chutes. The similarity of these calculated growth rates indicates that there may be considerable movement of river carpsuckers among the various habitats. Also, in many chutes and cutoff lakes where water levels drop as much as five feet in the fall, river carpsucker survival is dependent upon movement.

Maturity.-Maturity of the river carpsuckers examined could be related to both age and body length. In general, males were sexually mature when they had reached 12 inches total length. Most females, too, usually were mature when they had grown to 12 inches total length, but a few were not mature at 12.5 inches.

Males did not mature until the third year when $25 \%$ of those examined were sexually developed; however, one 9.6-inch male was mature at two years of age. Almost one-half of the four-year-old males examined were mature and, about $70 \%$ of the five-year-old males had reached maturity. Females did not begin maturing till the fourth year of life, when $25 \%$ of those examined were mature. Seventyfive percent of the five-year-old females were mature. One female was sexually developed when two years old and 10 inches long.

\section{Length-Weight Relationship}

A body length-weight relationship for 234 river carpsuckers captured in the cutoff lakes and chutes was computed after combining the data for both sexes. The fish were grouped into $10-\mathrm{mm}$ class intervals according to total lengths, and the average total lengths and weights in grams were noted for each interval. The length-weight

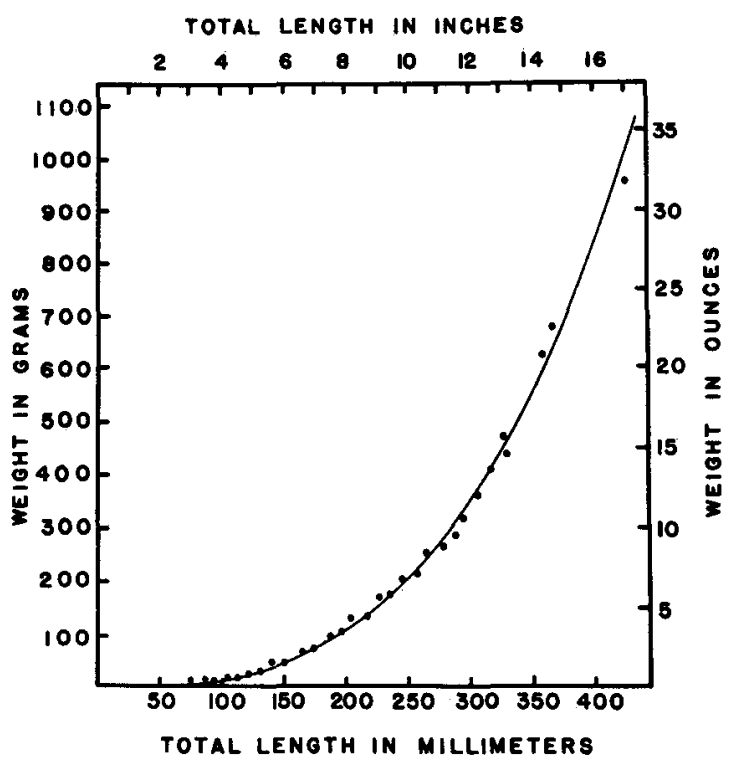

Fig. 2.-The length-weight relationship for river carpsuckers from the cutoff lakes and chutes along the Missouri River in Nebraska. 
relationship for these fish is described by the following equation: $\log W=-5.115+3.099 \log \mathrm{L}$, where $\mathrm{W}$ is the weight in grams and $\mathrm{L}$ is the length in millimeters.

The empirical data and calculated curve are presented in Fig. 2. In general, the calculated curve fitted the data very well. Greatest differences were noted where frequencies were the smallest.

The coefficient of condition of these fish, both sexes together, was computed using the following equation: $C=10^{5} \mathrm{~W} / \mathrm{L}^{3}$, where $\mathrm{W}$ is the weight in pounds and $\mathrm{L}$ is the total length in inches. Mean condition values of all class intervals ranged from 36 to 54 with no consistent change in condition through the various size groups.

\section{Discussion}

Results of limited trammel netting in the study area of the Missouri River indicate that river carpsucker populations may be large enough to sustain a harvest as a source of fertilizer or animal food. Numerically, river carpsuckers consistently comprised $35 \%$ to $85 \%$ of the catches of 24-hour net sets in cutoff lake habitats preferred by this species. The weight of river carpsuckers taken in these sets often exceeded 50 pounds per 250 -foot net.

On November 30, 1961, 71 fish were collected by the author and a commercial fisherman while drifting a trammel net in the main stream of the river. Forty-one (58\%) were river carpsuckers.

\section{REFERENGES}

Appleget, John, and L. L. Smith, JR. 1951. Determination of age and rate of growth from the vertebrae of the channel catfish, Ictalurus lacustris punctatus. Trans. Amer. Fish. Soc., 80:119-139.

Bass, J. C., And C. D. RigGs. 1959. Age and growth of the river carpsucker, Carpiodes carpio (Rafinesque), of Lake Texoma. Proc. Okla. Acad. Sci., 39:50-69.

Brezner, Jerome. 1956. Some aspects in the life history of the northern river carpsucker, Carpiodes carpio (Rafinesque), in the Niangua arm of the Lake of the Ozarks. M.A. thesis, University of Missouri, Columbia. $79 \mathrm{p}$.

Bughholz, Marvin. 1957. Age and growth of river carpsucker in Des Moines River, Iowa. Proc. Iowa Acad. Sci., 64:589-600.

Garlander, K. D., and L. L. Smith, JR. 1944. Some uses of nomographs in fish growth studies. Copeia, 1944:157-162.

Starrett, W. G. 1948. An ecological study of the minnows of the Des Moines River, Boone County, Iowa. Ph.D. thesis, Iowa State College, Ames. $161 \mathrm{p}$. 